\title{
Moral Dilemma Stories in Football Games to Develop Moral Judgment in Elementary School Students
}

\author{
Kama Abdul Hakam*, Ratna Fitriya \\ Dept. General/Value Education \\ Universitas Pendidikan Indonesia \\ Bandung, Indonesia \\ *kama.hakam@gmail.com, ratna.krestanto03@gmail.com
}

\author{
Siti Nurbayani \\ Dept. Social Studies \\ Universitas Pendidikan Indonesia \\ Bandung, Indonesia \\ s.nurbayani@upi.edu
}

\author{
Risa Wismaliya \\ Dept. Elementary Education \\ Universitas Pendidikan Indonesia \\ Bandung, Indonesia \\ wismaliyarisa@gmail.com
}

\begin{abstract}
The moral dilemma story developed by Kohlberg is part of moral education in schools, one of which is in Sports Physical Education and Health subjects in Elementary Schools. The purpose of this study is to provide a comprehensive description of the concepts and implementation of moral dilemma stories in football games to develop moral judgment of elementary school students. This study is based on product development by using an internal test of moral dilemma stories in the game of football by expert judgment. This research produces various moral dilemma stories in football games that can be used as material to develop moral judgment of elementary school students. The result of an internal test from expert judgment is that sports not only to build moral behavior but can be used as a media to develop maturity of students' moral judgment.
\end{abstract}

Keywords: football games, moral dilemma stories, moral judgment

\section{INTRODUCTION}

Moral dilemma is one of the media in developing moral judgment. [1-3]. Along with the needs in the field, researchers and teachers in various schools develop moral dilemmas in several types of creativity. They developed one of the types into a moral dilemma story in picture form Wismaliya et al. it aims to be adjusted at the elementary school level to the age according to its characteristics [4]. In contrast to the moral dilemma which is developed by Sarbaini this moral dilemma is presented in the form of moral discussion which is examined through a questions from the answers of middle school students [3].

Moral dilemma stories can be adapted into a subjects. It is raised Previously in Citizenship Education subject, now moral dilemma stories can be used as teaching material or media in Indonesian subject [4], Sciences [5], thematic learning [6] and in this research, it will be developed in Health and Physical Education subjects in Elementary School. So this research aims to develop a moral dilemma stories in a football game.
Sports subject at the elementary school level is a subject which are usually held by one of the sport teachers. Nevertheless, the classroom teacher must be able to play the role of a sports teacher if there is no sport teacher in the school. Some interesting things from this subject are that children love sports subjects which are done outside the classroom [7]. In the content of sports subject in elementary schools, it is true that practice holds greater weight than theory because sports subject aims to increase physical abilities and skills, growth, intelligence and character formation as well as a foundation for competitive sport and sport competition in the Olympic [8]. And the subject matter of the game (big balls \& small balls) dominates over theory, such as football game. In the curriculum of Physical Education, Sports and Health in Elementary School has a scope of material including 1) Games and sports include football, 2) Development activities, 3) Gymnastics Activities, 4) Rhythmic Activities, 5) Water Activities, 6) Outside Class Education, and 7) Health [9]. Students prefer to do activities outside the classroom and move their limbs happily [10].

Football game is not only part of sport and physical education subject that provide material and kinesthetic development for children at primary school age, but also can be a means in character education and moral development of students. There will be a lot of values that children develop in football game, such as the game taking place or during reflections or evaluations that make football play more meaningful and can develop student morale.

At the stage of reflection in learning evaluation, what teachers usually miss is the assessment of moral problems that children have gotten from a number of learning activities [11]. The point is not only a matter of evaluation in the cognitive field but also student moral reflection. One of them is the moral dilemma story in the football game.

This is based on evaluation of learning which is only a motoric test while moral reflection is needed of every actions 
which are taken by students in learning activities [12]. So that the teacher can give a moral dilemma stories of sport game that also connect between stories and the activities they have done, so that students get the same experience.

The moral dilemma stories is to develop moral considerations of elementary school students. This is important to be realized by educators, so that in the end the football game is not only as a sport game in the subject, but also has more use to develop student morale [13-15].

The existence of reciprocity in this study, exercise is more meaningful because it is not only fostering motor students but can foster and develop student morality. In contrast, moral dilemmas are not only able to develop students' moral judgment through hypothetical moral dilemmas, but can also be done through actual moral dilemmas of football game. So that mutualism occurs, moral dilemmas can increase the significance of sport education, and it becomes the material of actual moral dilemmas in moral education. Until now, moral dilemmas have been developed more hypothetically, and sports have only been fostering motor skills.

The research gap on this study is that cognitive moral development was not previously used in sports education, both hypothetical moral dilemmas and factual moral dilemmas [16]. In addition, sports education in character building has not yet used a hypothetical moral dilemma or factual moral dilemma, especially in increasing moral judgment [17]. Character development in sports education is more explained as an effort to train, not to increase moral judgment. So the objective is how sports education can improve moral judgment through hypothetical moral dilemmas and factual moral dilemmas in sports education [18]. The purpose is how sports education can collaborate on moral reasoning not just on moral action. So that sports education which has been building moral behavior, while this research is how sports education is used for develop moral judgment.

\section{MATERIAL AND METHOD}

This study uses a development method (Development Research) using a 4D model development approach (four-D model). The stages of the development model include the defining stage, the design stage, the development stage, and the dissemination stage. The stages carried out in this research only reach the stage of development and broad dissemination will be carried out through policy studies of the directorate of basic education. Educational Research and Development is a process used to develop and validate educational products [19].

The defining stage begins when defining the moral dilemma stories in the football game. At this stage the literature study is carried out as a preliminary study and examines the curriculum of sports subject at the elementary school level, especially in the high class. Various references from books or journals are designed as review literature.

At the design stage, starting from the elements that must be present in the moral dilemma stories in the football game, including the planning of the story that will be presented. In essence, we will synthesize the moral dilemmas which are developed theoretically by Kohlberg and the situation of the reality of sport education through football game. At this stage, the selection of the theme of a football game story involves developing the competitive and collaborative dilemmatic value, then sportsmanship and achievement, finally the dilemmatic value of professional and humanist. In addition, at the design stage for products, the design of instruments for testing the feasibility of the product is prepared by planning a number of assessments to validate the moral dilemma stories for experts to assess what has been planned. The expert judgments that validate the moral dilemma stories in sport games include expert in writing moral dilemmas, expert in sports games, and expert in basic education, especially in the psychology development of elementary school age.

The next stage is the development stage. At this stage the moral dilemma stories in the football game is developed in accordance with the refinement and input from the expert judgment until the assessment format meets $90 \%$. In the end, the development of the moral dilemma stories in the football game have been made in accordance with the development stages of elementary school age students to develop moral judgment.

The last stage is dissemination. This stage will be done further with more careful planning in publicizing the research and the product design that has been developed. One of the steps is to publish this research in indexed journals or proceedings. In addition, there was a workshop for elementary school teachers and sports teachers in elementary schools to convey a moral cognitive learning model by using moral dilemma story media on sport subjects to develop students' moral judgment. [20]

The elementary school students are the upper class students, between grade IV to grade VI students or children aged 10-12 years. In addition, it is necessary to review the curriculum or syllabus of high grade students in elementary school. This adjustment is in order to that teaching materials are in accordance with the content competencies and basic competencies. The judgment is because the children are already relatively able to discuss, can be invited to work together, and get to know the competition.

\section{RESULTS}

Dilemma stories in football game are devided into several parts. The first part is title, the second part is introduction, the third part is conflict sentence, and the fourth part is dilemmatic sentence. The final dilemmatic sentence is the culmination of a moral dilemma story, there has typical words in the form of a question "if you become ....", this sentence will lead the reader to feel and enter as a character [21,22]. Moral dilemma stories have principles, including 1) the sentence is to the point, 2) it has true values between two dilemmatic options at the end of dilemmatic sentence, and 3) the options are balance [23,24].

The following is the development of moral dilemma story design in football game. 
The title of the story above is injury. The word injury is

TABLE I. THE FIRST MORAL Dilemma Story

\begin{tabular}{|l|l|}
\hline \multicolumn{1}{|c|}{ Title } & \multicolumn{1}{c|}{\begin{tabular}{c}
\multicolumn{1}{c|}{ Winner } \\
(Competitive and collaborative value)
\end{tabular}} \\
\hline Introduction & $\begin{array}{l}\text { Tomi joined a football match in the district level. } \\
\text { His parents promised to give a gift if he made a } \\
\text { score. Tomi as a wing- forward. }\end{array}$ \\
\hline Conflict & $\begin{array}{l}\text { When the front position is about to kick the ball into } \\
\text { the goal, Tomi saw Andri was at the left of the goal } \\
\text { ready to receive the ball from him. While the } \\
\text { opponent's keeper was ready to catch the ball, and } \\
\text { the back position was ready to beat him. }\end{array}$ \\
\hline Dilemmatic part & $\begin{array}{l}\text { If you become Tomi what would you do? give the } \\
\text { ball to Andri and Andri is likely to make score or } \\
\text { try hard to keep the opponent in front to bring the } \\
\text { ball by yourself to make score? }\end{array}$ \\
\hline
\end{tabular}

The moral dilemma stories above take the title of Winner. The developed values are competitive and collaborative. Both of these values are balance, so that between choice $\mathrm{A}$ and choice B does not mean right and wrong. The title is taken by the word Winner means that the child who was playing the football is a winner because he was able to make wise decisions on the grounds behind the choice.

In the introduction stage, Tomi's character is introduced by describing the story that he will get a gift from his parents if he scored a goal, this is intended as an angler to conflict and the dilemmatic situation in the next sentence. His position as a wing-forward is also an introduction that this is part of the player formation in football game [25].

In the conflict part, Tomi was positioned in a situation where making score was possible, then the opposite position is represented by the position of Andri who was on the left also ready to make score. This thing implies collaborative value in a football game. But if you remember the introduction, there was an interesting offer from Tomi's parents if he could make score. It contains a competitive value in himself as a person who has to make score even though before him there was opponent from other teams who will drive him away.

The conflict part above led Tomi to the dilemma situation of choosing to pass the ball to Andri or keep the ball on his feet and he tried to make score. The dilemmatic sentence is balance. Students choose the choice of passing the ball to Andri and bringing the ball themselves both have true and balanced values. Because in the end, the teacher will see the reasons behind these choices. These reasons describe the stages of children's moral judgments which are examined with questions and answers and interviews.

TABLE II. THE SECOND OF MORAL DILEMMA STORY

\begin{tabular}{|l|l|}
\hline \multicolumn{1}{|c|}{ Title } & \multicolumn{1}{c|}{ Injury (Sportsmanship and achievement value) } \\
\hline $\begin{array}{l}\text { Introduc } \\
\text { tion }\end{array}$ & $\begin{array}{l}\text { While playing football between schools, Gilang as the } \\
\text { captain of his football team suffered injury due to colliding } \\
\text { with the team from the opposing school. Finally he rested } \\
\text { and was replaced by a reserve player. }\end{array}$ \\
\hline Conflict & $\begin{array}{l}\text { The game was over. The winner was the opposing school. } \\
\text { Gilang felt sorry for himself because of his injury and stop } \\
\text { playing. He was thinking that he would play hard to win the } \\
\text { game even less when he got injury the opponent didn't get } \\
\text { the yellow card but just a warning. }\end{array}$ \\
\hline $\begin{array}{l}\text { Dilemma } \\
\text { tic part }\end{array}$ & $\begin{array}{l}\text { If you become Gilang, would you congratulate the opposing } \\
\text { team? or just stay in the chair with the reason being injured? }\end{array}$ \\
\hline
\end{tabular}

usually heard in a sport game, including the football game. It is as a reminder of some vocabularies in football game. The value that he developed is the value of sportsmanship and achievement. These values are a contradiction but they have a balance in dilemmatic choice. Students are expected to develop sportsmanship and achievement values in playing football.

In the introduction part, the character Gilang is considered as the main player in the game as a captain. But he was positioned as a player who suffered an injury. He have to break for a moment and be replaced by a reserve player, it will lead to a conflict sentence that is burdened by the referee's situation that did not give a yellow card to the opponent's team who has injured his leg.

In the conflict part, it was complicated by the victory of the opposing team over the game. So that at the end of the dilemmatic sentence, the student had a moral dilemma between congratulating the opposing team who has injured him without accepting yellow card from the referee or he just sits on the grounds of being injured in order to avoid disappointed feeling in football.

TABLE III. THE THIRD OF MORAL DILEMMA STORY

\begin{tabular}{|c|c|}
\hline Title & $\begin{array}{c}\text { Scoring a goal } \\
\text { (Professional and humanist value) }\end{array}$ \\
\hline Introduction & $\begin{array}{l}\text { Dani played as a back player in a football game. He } \\
\text { tried to banish any enemy who would make a score. }\end{array}$ \\
\hline Conflict & $\begin{array}{l}\text { When the opposing team is about to score against } \\
\text { Dani, he was overwhelmed by the speeding ball, the } \\
\text { only way to stop the ball is by kicking it to the } \\
\text { sideways but with the body falling and blocking the } \\
\text { way of the opposing team to step forward, it is called } \\
\text { tackle in the game. }\end{array}$ \\
\hline Dilematic part & $\begin{array}{l}\text { If you become Dani, will you do the tackle so that the } \\
\text { ball does not enter the goal, or will you drive the ball } \\
\text { normally and the ball has a chance to enter the goal? }\end{array}$ \\
\hline
\end{tabular}

In the moral dilemma story above, the title is scoring a goal and it developed professional and humanist values. The purpose of these values are to contain a dilemma meaning between the value that is supposed to be done as a football player and also the humanist sense of the player with other players that focuses on direct physical competition when playing.

In the introduction sentence, Dani is introduced as a defender whose job is to block the ball. So it is embedded in him to try to prevent opponents from entering the area near the goal.

It triggered a sentence of conflict when the opposing team drove dribbling quickly, and Dani was stunned so that there was only one choice that he could make the ball did not enter the goal. The conflict sentence contained his professional value as a defender and also his humanist sense as a human being who did not have to hurt other humans, which in this story was the physical / body of the opponent.

The dilemmatic sentence of course makes a choice between saving the ball by tackling or not doing tackle because it is dangerous for the physical safety of the opponent. 
[9] Ministry of Republic of Indonesia, Materi PelatihanGuru Implementasi Kurikulum 2013. Jakarta: Badan Pengembangan Sumber daya Manusia Pendidikan dan Kebudayaan dan Penjaminan Mutu Pendidikan Kemendikbud, 2013.

The three moral dilemma stories above with the development of values that have been assessed by expert judgment shows that students will be in these conditions with actual way or with the story description.

The next step after the students read the moral dilemma stories in developing moral judgment is to measure the maturity of moral judgment by using the moral judgment which was developed by Kohlberg [26-28] There are 6 stages of moral judgments by Kohlberg in three levels. Those are pre conventional, conventional and post conventional.

The teacher prepares various reasons that can be chosen by students by considering the characteristics of elementary school students who are still at a concrete operational stage [29]. Each answer that the students choose is a picture of moral judgment that has been developed by James Rest [21]

\section{CONCLUSION}

Sports education is not only can bequeath and provide a training in moral values or character to students, but it can also be an ingredient in an actual dilemma in increasing the maturity of students' moral judgment. The conflicts that arise in sports games can be raised as consideration material for moral dilemma stories and sports games, not only resolved in the field in moral behavior decisions form but can also be followed up by discussing the actual dilemmas in the sport game. So, sports education can be a media for passing down moral values in the form of moral behavior and also increasing the maturity of students' moral judgment in elementary school.

\section{REFERENCES}

[1] Kohlberg, Moral Development. United Kingdom: Cambridge Univ. Press, 1984.

[2] K.A. Hakam, "MODEL OF LEARNING COGNITIVE MORAL DEVELOPMENT IN ELEMENTARY SCHOOL," International EJournal of Advances in Education, vol. 4(10), pp. 6-14, 2018.

[3] Sarbaini, Model Pembelajaran Berbasis Kognitif Moral. Yogyakarta: Aswaja Pressindo, 2012.

[4] R. Wismaliya, K.A. Hakam, and M. Agustin, "MODEL OF LEARNING COGNITIVE MORAL DEVELOPMENT THROUGH PICTORIAL STORY IN ELEMENTARY SCHOOL," International E-Journal of Advances in Education, vol. 4(10), pp. 77-85, 2018.

[5] K.A. Hakam, R. Wismaliya, and A. Setiawan, "Socializing Habitual Healthy Lifestyle to Lower Primary Student Using Sticky Note Checklist Media," IOP J. Phys. Conf. Ser., 2019.

[6] R. Satianingsih., B. Maftuh, and E. Syaodih, "Moral Cognitive Development of Primary School Students in Thematic Integrated Curriculum," vol. 174, no. Ice 2017, pp. 402-406, 2018.

[7] K. Love and J. Hamston, "Committed and Reluctant Male Teenage Readers.pdf," pp. 335-400, 2015.

[8] R. Lutan, Pembaharuan Pendidikan Jasmani di Indonesia. Jakarta: Depdiknas Dirjen Dikdasmen Dirjen Olahraga., 2001.
[10] W.L.M. Hoffman, Bebas dari Penyakit Mencegah, Mengobati, danMenyembuhkan dari 100 Penyakit dan Idapan. Jakarta: Gramedia Pustaka Utama, 1996.

[11] A. Nurzaqi and S. Rahayu, "Materi Pembelajaran Tematik Pendidikan Jasmani Olahraga Dan Kesehatan Untuk Siswa Sekolah Dasar," Journal of Physical Education and Sports, vol. 4(1), 2015.

[12] Kemdikbud, SILABUS PENJAS SD KURIKULUM 2013. Jakarta: Kementrian Pendidikan dan Kebudayaan, 2015.

[13] W. Althof and M.W. Berkowitz, "Moral education and character education: their relationship and roles in citizenship education," J. Moral Educ., vol. 35, no. 4, pp. 495-518, 2006.

[14] C.R. Beal, A. Garrod, K. Ruben, T.L. Stewart, and D.J. Dekle, "Children's Moral Orientation: does the gender of dilemma character make a difference?," J. Moral Educ., vol. 26, no. 1, pp. 45-58, 1997.

[15] R. Curren, "Aristotelian versus virtue ethical character education," J. Moral Educ., vol. 45, no. 4, pp. 516-526, 2016.

[16] Sheryle Bergmann Drewe, "Moral Reasoning in Sport: Implications for Physical Education,” J. Curric. Stud., vol. 32, no. 4, pp. 117-130, 2000.

[17] C. Jones and M. McNamee, "Moral Reasoning, Moral Action, and the Moral Atmosphere of Sport," Sport. Educ. Soc., vol. 5, no. 2, pp. 131146, 2000.

[18] L. Hsu, "Moral thinking, sports rules and education1," Sport. Educ. Soc., vol. 9, no. 143-154, 2004.

[19] W.R. Borg, J.P. Gall, and M.D. Gall, Educational Research: An Introduction (5th ed.). New York: Longman, 1989.

[20] Z. K. Papageorgaki, "Researching the lived experience of physical education: some pedagogical insights," Sport. Educ. Soc., vol. 23, no. 9, pp. 916-927, 2018.

[21] J.R. Rest, D. Narvaez, S.J. Thoma, and M.J. Bebeau, "A NeoKohlbergian Approach to Morality Research,” J. Moral Educ., vol. 29, no. 4, pp. 381-395, 2000.

[22] M. Hasegawa, "Development of moral emotions and decision-making 387-399, 2016.

[23] H.E. Kaufman, "Moral and Ethical Issues Related to Academic Dishonesty on College Campuses," J. Coll. Character, vol. 9, no. 5, pp. 08,2008 .

[24] D. Lapsley and R. Woodbury, "Moral-Character Development for Teacher Education," Action Teach. Educ., vol. 38, no. 3, pp. 194-206, 2016.

[25] R. Pratama, Santoso, and Y.A. Sari, "Penentuan Posisi Pemain Sepak Bola Menggunakan Metode AHP dan TOPSIS,” J. Pengemb. Teknol. Inf. dan Ilmu Komput. Univ. Brawijaya, vol. 2, no. 7, pp. 2471-2476, 2018.

[26] S. Verducci, "A Moral Method? Thoughts on cultivating empathy through Method acting," J. Moral Educ., vol. 29, no. 1, pp. 87-99, 2000.

[27] L. Nucci, "Recovering the role of reasoning in moral education to address inequity and social justice," J. Moral Educ., vol. 45, no. 3, pp. 291-307, 2016.

[28] M. Paciello, R. Fida, C. Tramontano, E. Cole, and L. Cerniglia, "Moral dilemma in adolescence: The role of values, prosocial moral reasoning and moral disengagement in helping decision making," Eur. J. Dev. Psychol., vol. 10, no. 2, pp. 190-205, 2013.

[29] E. Doyle, "The Impact of Education Level and Type on Moral Reasoning," Irish Educ. Stud., vol. 32, no. 3, pp. 377-393, 2013. from childhood to young adulthood," J. Moral Educ., vol. 45, no. 4, pp. 